\title{
Climate-Smart Bread
}

\begin{abstract}
Globally we produce 700 million tonnes of wheat each year, providing one-fifth of all the calories and proteins we consume. An average loaf of bread has a carbon footprint of 1 kilogram, mainly as a result of emission on the farm. We also waste a huge amount: over 700,000 tonnes is thrown away each year in the UK-the equivalent of more than two million loaves a day and about one-third of all the bread we buy. Alongside reducing household waste, improved efficiency of nitrogen fertiliser use is a key way to cut emissions. Wheat is already facing impacts on yields from climate change, with heat waves, drought and disease being major risks in many areas in the coming decades. Access to disease-resistant varieties and use of improved soil management can both boost resilience and reduce emissions.
\end{abstract}

Keywords Wheat $\bullet$ Flour $\bullet$ Food waste $\bullet$ Carbon footprint $\bullet$ Heat stress $\bullet$ Fusarium $\bullet$ Mycotoxins $\bullet$ Disease resistance $\bullet$ Soil organic matter $\bullet$ Drainage $\bullet$ Precision agriculture

Since the dawn of agriculture, bread has been the yeast-heavy fuel for much of human civilisation. Most is now made using wheat flour, with a seemingly endless array of shapes, flour mixes and bakes available. Millions of working days begin with a slice or two of toast, hastily smeared with butter and bolted down with one hand on the car keys, umbrella or

(C) The Author(s) 2019

D. Reay, Climate-Smart Food, https://doi.org/10.1007/978-3-030-18206-9_3 
screaming toddler [1]. Here in Scotland, we eat our way through over 700,000 loaves each day [2], with most of these being the white pre-sliced favourite of sandwich and toast-making.

In our house, the misshapen rolls and part-blackened loaves on offer are usually courtesy of my own amateur baking efforts. These unpredictable experiments in bread-making rely on bags of strong flour in each weekly food shop. Though the bulk of bread flour sold here in the UK is home grown, up to one-fifth is imported from Canada due to the particular strengthening qualities their flour possesses. Globally though, it is China and the US that lead the way on wheat production, with Russia and India also being big players (Fig. 3.1).

Wheat is a true global staple. As well as giving us bread, it is the basis for myriad pastas, cakes, breakfast cereals and snacks. It's also a major food source for livestock. The 700 million tonnes produced worldwide each year $[4,5]$ provide one-fifth of all the calories and proteins we consume

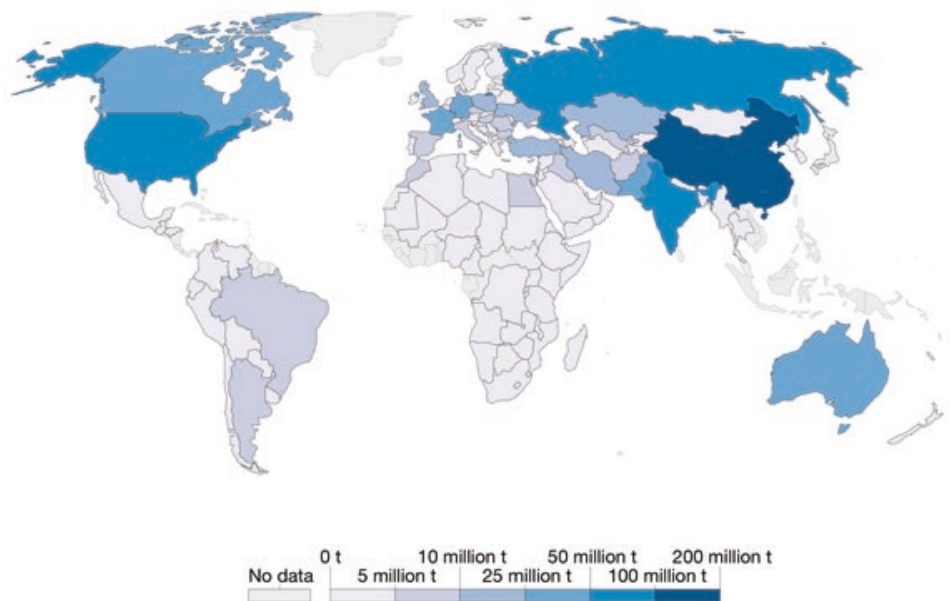

Fig. 3.1 Global wheat production in 2014 by country of origin (Source: Hannah Ritchie, Our World in Data) [3]. Available at: https://ourworldindata.org/ grapher/wheat-production 
[6], and there are now more than 200 million hectares of land dedicated to its production (the biggest area of any crop on the planet) [7].

Wheat-growing practice has seen huge leaps over the last 50 years. Pressure to wring bigger and bigger yields from the world's fields has meant burgeoning use of artificial fertilisers, high-yield varieties, pesticides and irrigation [8]. The initial results were stunning. As access to the powerful tools of this Green Revolution spread from developed nations to developing nations in the 1960s, so yields surged across Latin America, Asia and North Africa. The new high-yield wheat varieties had shorter stems, and so were less prone to falling over in high winds. They could also reach maturity faster and better convert added fertilisers into bumper crops.

This bonanza period for global wheat production could not be sustained. By the 1980s the big year-on-year increases in harvests were starting to falter, with problems of unequal access to fertilisers and new crop varieties being common. By the 1990s and early 2000s increasing numbers of farmers were finding that crop losses, due to problems like increasing soil salinity and waterlogging, were undermining the yield-boosting effects of big fertiliser, pesticide and irrigation inputs.

Gradually emerging as a fundamental threat to global wheat production over this period has been climate change [9]. Rising carbon dioxide concentrations in the atmosphere initially seemed a boon-the feast of nutrients supplied by artificial fertilisers together with big improvements in water management allowing the crops to take fuller benefit of this carbon dioxide enrichment effect. Yet as carbon dioxide concentrations have risen, so global temperature has also increased and precipitation patterns changed. Since 1980 rising temperatures are estimated to have sliced around 5 per cent off global wheat yields [10].

For most wheat production, disentangling the effects of rising temperature from changes in water availability and farming practices remains difficult.

Yet warning signs of wheat's sensitivity to severe weather, and the knock-on effects for global food security, were already clear in 1972 when a combination of low rainfall and record temperatures hit yields in Russia. That summer peak temperatures pushed past 30 degrees Celsius just as the Russian wheat crop was developing [11]. Harvests fell by more than a tenth, with the decision by the Russian government to then buy from the global wheat market pushing up world prices and sparking fears of food shortages in other nations. 
Today, much of the world's wheat is grown in areas that are experiencing both rising temperatures and falling water availability-a potential double-risk as the water demand of wheat plants increases as temperatures rise. The higher temperatures also tend to speed up plant growth and so shorten its growing time [12]. For the key period when the plants would normally be developing their grains, this can mean much smaller wheat grains are produced and overall yields can be more than halved [4].

While gradual increases in temperature may actually enhance wheat yields in some places (at high latitudes where low temperatures currently restrict crop growth for instance), it is an increase in extreme events like heat waves and droughts that poses the biggest risk in many areas [5]. Recent decades have seen the High Plains farmers of Dakota and Montana reaping the benefits of a warming climate, overtaking Kansas as top wheatproducing area in the US. Yet in 2017 this same area was hit with one of the most severe droughts on record.

As the wheat-growing season began, so the rainfall petered out. By August rainfall across the region was down to half the normal level, with some places receiving less than a quarter of their expected rain [13]. Described as a flash drought because of its sudden onset and severity, the combination of thirsty plants, high temperatures and vanishing rainfall hit both wheat yield and quality hard $[14,15]$. Total production in the region was down by around a quarter compared to the average, with over 200,000 hectares of North Dakota wheat fields never making it through to harvest. The speed and unprecedented nature of this drought in some areas made pre-emptive action by farmers near impossible. Droughts predictions are given each year, based on factors like the size of the spring snowpack and seasonal temperatures, but these forecast methods can still be side-swiped by flash droughts [16].

North Dakota has already seen the fastest increase in average temperatures anywhere in the contiguous US [17]. With further warming (the number of days over 100 degrees Fahrenheit is set to double by 2050) and even larger swings in water availability predicted, the High Plains farmers face a choice between investing in expensive irrigation systems or trying to build these new extremes into their management plans [14].

For our own great British loaf, wheat farmers in the UK have largely been spared such flash drought and high temperature threats. Instead, it is the challenge of too much water, at the wrong time and in the wrong place that most risks damaging yields and further inflating the climate cost of our daily bread. 
The carbon footprint of bread depends on how and where the wheat is grown, its processing and production, and how we then choose to consume it [18]. Across its life cycle the average family loaf-including my own home-baked blobs-will clock up around one kilogram of emissions. Growing the wheat is the biggest part of this, at one-third of the total, and mostly arises from the nitrogen fertilisers used to boost yields. Consumer use of the bread-such as the energy used if we keep it in the fridge or toast it - then makes up another quarter of the emissions. The rest comes from processing, packaging, transport and other ingredients like salt, sugar and yeast. Although bread made with imported flour can have a slightly higher carbon footprint, transport emissions are only a small part of this difference, with the wheat-growing practices of the source farms being much more important.

For households, using all the bread that we buy, rather than wasting it, is the most powerful way for most of us to reduce its carbon footprint-in the appetite-killing world of food waste statistics bread is in a class of its own. In the UK over 700,000 tonnes are thrown away each year-the equivalent of more than two million loaves a day and about one-third of all the bread we buy. The climate cost is a global embarrassment at over half a million tonnes of greenhouse gas.

Almost all is classed as avoidable and is mainly due to the bread not being used in time [19]. Additional waste arises from personal tastes and that perennial sandwich leftover: crusts. Not over-buying, keeping it well wrapped or frozen [20], and using even those tantrum-inducing crusts can therefore avoid unnecessary land, fertiliser and pesticide use, and so play a major role in lowering bread's overall carbon footprint. In wheat fields around the world a similar battle to prevent loss and waste is one that has been fought by generations of farmers.

Most UK wheat-some two million hectares providing a harvest worth over $£ 2$ billion a year-is grown as so-called winter wheat. The seeds are sown in the autumn and then harvested in July to September of the following year. As climate change intensifies the UK is set to experience drier, hotter summers alongside warmer, wetter winters. Since the 1960s, average summer temperatures have risen by around 1 degree Celsius [21] and rainfall has dropped by a tenth in many regions [22]. For the bulk of wheat farmers this trend has helped lengthen the growing season and, 
along with new technology and wheat varieties, has boosted yields [23]. However, winter precipitation has increased markedly too, with all regions getting wetter and some areas of Scotland now seeing 60 per cent more rain and snow.

On heavy clay-rich soils, persistent rains and waterlogging can induce low oxygen conditions that damage plant roots, while precious nutrients and soil organic matter are lost to field drains via run-off and leaching. A really heavy downpour will also bend wheat stems, pushing the drenched plants into the dark, moist and windless under-storey of the wheat crop where pests and fungal diseases can thrive [24].

In 2012 Britain endured one of its wettest years on record. After a warm and dry start to the year, accompanied by initial concerns over drought, England and Wales then saw their wettest April and June since 1766 and the wettest summer season overall since 1912 [25]. By that autumn, soils were saturated and the rain just kept on coming [26]. Hundreds of homes and businesses were flooded, transport links were cut, and costs spiralled to near $£ 600$ million [27]. Many farms were badly hit. Honey production was more than halved, apple growers faced their worst harvest in 15 years [28], and potato farmers their worst in over three decades [29].

In comparison wheat got off lightly-the total harvest in the UK was down 13 per cent on the previous year [30]. Farmers then faced the choice between not planting winter wheat at all or trying to sow their sodden fields with the risk of bogged-down machinery, damaged soil structure and poor harvests in the following year too. Many opted for the former, with 400,000 hectares of land normally planted with wheat either used for growing different crops or abandoned to the winter rains [31].

The 2013 wheat harvest was inevitably a poor one. Some farmers who had initially braved the muddy fields found wheat growth so poor that they grubbed up the struggling crop and planted with barley instead [32]. For the first time in over a decade the UK became a net importer of wheat as total yields slipped a further 8 per cent, compounding the losses of 2012 [31]. Grain prices were pushed to record highs, with the price of everything from bread and breakfast cereals to beer and beef being affected.

The waterlogged and abandoned wheat fields of 2012 and 2013 were an all too obvious sign of severe weather impacts, but hidden within most swaying stands of outwardly healthy wheat a host of additional threats lurk that may become super-charged by climate change. 
Wheat has many enemies. Globally, weeds are one of its biggest adversaries, hitting yields by crowding out seedlings and capturing the water and nutrients intended for the crop. The swathes of closely packed wheat plants now grown in much of the world also represent a rich target for any pests and diseases able to invade them. Worldwide, bacteria, viruses and fungal diseases, already have major impacts on yields. Between 2001 and 2003 fungal and bacterial disease were responsible for an estimated 10 per cent of global wheat losses [33].

Through changes in rainfall, temperature and plant growth, climate change will alter the spread and impact of such diseases in many areas [7]. In the moist air and soils of the UK, fungal diseases-ranging from 'rusts' and 'blights' to 'smuts' and 'bunts'-now pose a major threat. Public enemy number one for many British wheat farmers are fungi belonging to the Fusarium family. Given warm and wet conditions these fungi can invade the wheat plants just as they are starting to flower. The fungal blight appears as bleaching of the ears of wheat, along with clusters of pink or orange fungal spores [34]. In bad years the spread of this Fusarium Ear Blight in the UK can reach epidemic proportions, with eight out of ten wheat crops sampled in 2007 showing signs of infection. As a result there can be big losses in yield and quality, but the most damaging impact is often a more cryptic and highly toxic one. The invading fungi can produce toxins (called mycotoxins) that, if present in the wheat grains, are dangerous to any animals or humans that then consume them [35]. In livestock, consumption of heavily contaminated grain can lead to loss of appetite, weight loss and vomiting. In humans its effects may include dizziness, abdominal pain and fever.

How exactly climate change will affect fungi and other wheat pests and diseases around the world remains uncertain. In the UK, modelling studies suggest an increase in the intensity of Fusarium epidemics, especially in the south of England, through to 2050 [34]. Likewise, an increase in Fusarium infections in some parts of Brazil and Uruguay is expected, while some other fungal diseases (such as the charmingly named Karnal Bunt) may actually decrease in the Punjab region of India due to changing temperature and humidity [36]. A future atmosphere enriched with more carbon dioxide adds to the uncertainty-though wheat plants may grow faster, their many pests and diseases could also benefit [37].

What is certain is that a changing climate will indirectly affect wheat yields through its impacts on weeds, pests and diseases, as well as through the more direct effects of changing temperature and rainfall on plant 
growth. On its trajectory of warmer, wetter winters, and increasing risks of extreme weather, pest and disease impacts, UK wheat production is set to experience the same rollercoaster ride of peaks and troughs being faced around the world. Where these troughs are global, and wheat prices spike, they could pose a very real danger to the food security of millions.

A climate-smart response for wheat growers, wherever they are in the world, will need to try and take account of both the direct and indirect risks from climate change. Dealing with heavy rainfall and saturated soils has become second nature for many British farmers, with a proven adaptation response being to avoid planting wheat altogether in very wet years. In some areas with high rainfall or heavy, clay-rich soils, installing or improving land drainage can help to prevent waterlogging and ensure that planting, growth and harvest can still go ahead. However, drainage can be a costly solution - it usually involves permeable pipes being laid at regular intervals under the soil and so requires specialised equipment, and good maintenance. In some cases these soil drains also increase the risks of nutrients being carried away from the fields along with the drainage water [38].

Careful management of soils and their structure is often a very effective way to reduce the need for extra drainage and to boost the resilience of the fields to extreme rainfall, as well as to many drought, pest and disease risks. Reducing compaction of the soils for instance, by avoiding heavy machinery use when they are saturated, helps keep the air spaces within the soil open and so maintains their permeability. Likewise, increasing the organic matter in soils [39] — such as by incorporating manures and reducing the amounts and depth of tillage-can improve soil structure and its drainage properties [40]. Such deliberate management of carbon in soils is a climate-smart food solution that can truly pull off the triple-win trick of increasing climate change resilience, boosting yields and enhancing carbon stocks [39].

For those wheat farmers able to afford them, a suite of new technologies may play an important role in maximising yields and dealing with weather extremes. Accessing waterlogged fields without causing severe damage to soil structure has been made easier with the development of lighter tractors and caterpillar tracks that spread weight better. The expansion of precision agriculture-whereby nutrients and pesticides can be 
delivered more precisely to where they are needed - now includes satellite data, soil moisture sensors, and even remotely controlled drones that are used to survey crops from the air and identify waterlogged, diseased or under-fertilised areas that need attention [41].

Less eye-catching, but arguably more important, is the widespread practice of soil monitoring, farm nutrient budgeting, and the use of long range weather forecasting to help inform planting and field management decisions $[42,43]$. An increasing number of 'decision-support' tools are available to wheat farmers, ranging from free-to-use online applications specifically aimed at reducing greenhouse gas emissions from agriculture [44], to pay-for platforms that claim to provide seasonal forecast and weather data at the level of individual fields up to 3 months in advance [45].

For major wheat pests and diseases like Fusarium blight there are similar online tools and advice designed to support growers and assess the level of risk based on location, time of year and weather conditions [46]. As well as helping to give early warning of potential disease outbreaks, these sources of information include guidance on how best to harvest, store and process the wheat so as to minimise infection and toxins, and therefore cut overall losses. As global trade in wheat increases-including years of big wheat imports to the UK-the risk of disease spread is likely to grow and the need for early warning and robust quarantine systems becomes even more important.

Development of new types of disease-resistant wheat is a potentially very powerful way to increase resilience [47], with the search for wheat plants that are both higher yielding and better adapted for future climate change having become a global undertaking [48]. A big question in the development and use of climate-resilient wheat is that of exactly what the main climate change risks will be in any given location, and so which particular traits should be emphasised.

Developing plants that are more resistant to fungal infection might appear a good option for the UK, yet increased resistance to one threat can come at the cost of reduced defence against others [23, 49]. Understanding such trade-offs and preparing for future climate risks is a focus of the research that is currently underway. In some parts of Africa for instance, it is estimated to take over ten years for controls such as crop resistance to a new disease to be put in place [50]. If the risks of drought, flood or disease under a changing climate can be identified early then their impacts could be drastically reduced. 
As with any type of food, the most effective strategies for climate-smart wheat production will ultimately be those that are specific to the local context, that are cost-effective and that are readily accessible to farmers. The high level of expertise common to British wheat farmers, coupled with good access to technology, advice and cutting-edge research, means they are well placed to adapt to future climate change. There could be opportunities to expand wheat into new areas of the UK as growing seasons lengthen, while future summers may bring more of the heat and drought stress challenges already faced by farmers in the High Plains of the US [23].

Nationwide, there are still gaps in the provision of climate extension services (advice and support for farmers), and more locally specific assessments of climate risks and opportunities are definitely needed. However, these shortfalls are dwarfed by those faced by wheat farmers in most of the world. As the human population continues to rise and wheat demand spirals upward, climate change impacts pose a major risk for sustaining current harvests, let alone increasing them, in many nations [51]. Each degree centigrade of climate warming is predicted to slice another 6 per cent from global wheat production [23]. With one-fifth of our calories coming from wheat and its vulnerability to climate change being so high [52], making our daily bread more climate-smart is arguably one of the most important challenges facing agriculture in the twenty-first century.

\section{REFERENCES}

1. fabflour.co.uk. Facts about Bread. http://fabflour.co.uk/fab-bread/factsabout-bread/(2018).

2. nabim.org.uk. Flour \& Bread Consumption. http://www.nabim.org.uk/ flour-and-bread-consumption (2018).

3. Ritchie, H. Global wheat production, 2014. Ourworldindata.org. https:// ourworldindata.org/grapher/wheat-production (2018).

4. Asseng, S., Foster, I., \& Turner, N. C. The impact of temperature variability on wheat yields. Glob. Change Biol. 17, 997-1012 (2011).

5. Zampieri, M., Ceglar, A., Dentener, F. \& Toreti, A. Wheat yield loss attributable to heat waves, drought and water excess at the global, national and subnational scales. Environ. Res. Lett. 12, 064008 (2017).

6. Shiferaw, B. et al. Crops that feed the world 10. Past successes and future challenges to the role played by wheat in global food security. Food Secur. 5, 291-317 (2013). 
7. Juroszek, P. \& von Tiedemann, A. Climate change and potential future risks through wheat diseases: A review. Eur. J. Plant Pathol. 136, 21-33 (2013).

8. Pingali, P. L. Green revolution: Impacts, limits, and the path ahead. Proc. Natl. Acad. Sci. 109, 12302-12308 (2012).

9. Rosenzweig, C. \& Parry, M. L. Potential impact of climate change on world food supply. Nature 367, 133-138 (1994).

10. Lobell, D. B., Schlenker, W. \& Costa-Roberts, J. Climate trends and global crop production since 1980. Science, 1204531 (2011).

11. Battisti, D. S. \& Naylor, R. L. Historical warnings of future food insecurity with unprecedented seasonal heat. Science 323, 240-244 (2009).

12. Iqbal, M. et al. Impacts of heat stress on wheat: A critical review. Adv. Crop Sci. Technol. 5, 1-9 (2017).

13. Holthaus, E. 'Flash drought' could devastate half the High Plains wheat harvest. grist.org. https://grist.org/food/flash-drought-could-devastate-halfthe-high-plains-wheat-harvest/ (2017).

14. McLaughlin, K. The unprecedented drought that's crippling Montana and North Dakota. The Guardian. https://www.theguardian.com/environment $/ 2017 / \mathrm{sep} / 07 /$ flash-drought-north-dakota-montana-wildfires (2017).

15. Rooney, D. US winter wheat ratings slump in key growing states. $A H D B$ Cereals \& Oilseeds. https://cereals.ahdb.org.uk/markets/marketnews/2018/january/30/grain-market-daily-300118.aspx (2018).

16. Otkin, J. Hit hard by drought. toolkit.climate.gov. https://toolkit.climate. gov/case-studies/early-warning-information-increases-options-drought-mitigation (2017).

17. USEPA. Climate Impacts in the Great Plains. https://archive.epa.gov/epa/ climate-impacts/climate-impacts-great-plains.html (2017).

18. Espinoza-Orias, N., Stichnothe, H. \& Azapagic, A. The carbon footprint of bread. Int. J. Life Cycle Assess. 16, 351-365 (2011).

19. WRAP. Household food and drink waste in the United Kingdom 2012. Waste and Resource Action Programme. http://www.wrap.org.uk/sites/files/wrap/ hhfdw-2012-main.pdf.pdf (2013).

20. Taylor, A.-L. Why is bread Britain's most wasted food? BBC Online. http:// www.bbc.co.uk/news/magazine-17353707 (2012).

21. Carbonbrief. Mapped: How every part of the world has warmed-And could continue to warm. Carbonbrief.org. https://www.carbonbrief.org/mappedhow-every-part-of-the-world-has-warmed-and-could-continue-to-warm (2018).

22. Jenkins, G. J., Perry, M. C. \& Prior, M. J. The Climate of the UK and Recent Trends. UK Met Office. http://www.ukcip.org.uk/wp-content/PDFs/ UKCP09_Trends.pdf (2008).

23. Brown, I. et al. UK Climate Change Risk Assessment Evidence Report: Chapter 3, natural environment and natural assets. Report prepared for the 
Adaptation Sub-Committee of the Committee on Climate Change, London. (2016).

24. Mäkinen, H. et al. Sensitivity of European wheat to extreme weather. Field Crop. Res. 222, 209-217 (2018).

25. MetOffice. UK Weather-Annual 2012. https://www.metoffice.gov.uk/climate/uk/summaries/2012/annual (2013).

26. MetOffice. November 2012 Flooding. https://www.metoffice.gov.uk/learning/learn-about-the-weather/weather-phenomena/case-studies/november2012-flooding (2015).

27. UKEA. Floods Cost UK Economy Nearly £600 Million. http://webarchive. nationalarchives.gov.uk/20140223163833/http://www.environmentagency.gov.uk/news/150962 aspx?page=2 \&month=11 \&year=2013 (2013).

28. Morris, S. Apple growers face grim harvest with worst yield for 15 years. The Guardian. https://www.theguardian.com/lifeandstyle/2012/sep/16/ apple-growers-worst-yield-15-years (2012).

29. fwi.co.uk. 2012 Potato Crop Lowest Since 1976. http://www.fwi.co.uk/ arable/2012-potato-crop-lowest-since-1976.htm (2012).

30. DEFRA. Farming Statistics: Final Crop Areas, Yields, Livestock Populations and Agricultural Workforce at 1 June 2012, United Kingdom. Department for Environment, Food \& Rural Affairs, UK. http://webarchive.nationalarchives. gov.uk/20130125173510/http://www.defra.gov.uk/statistics/files/defrastats-foodfarm-landuselivestock-farmingstats-june-statsrelease-june 12 finaluk-121220.pdf (2012).

31. DEFRA. Farming Statistics: Provisional Crop Areas, Yields and Livestock Populations at June 2013, United Kingdom. Department for Environment, Food \& Rural Affairs, UK. https://www.gov.uk/government/uploads/system/uploads/attachment_data/file/251222/structure-jun2013prov-UK17octl3a.pdf (2013).

32. Vidal, J. Farmers fail to feed UK after extreme weather hits wheat crop. The Guardian. https://www.theguardian.com/environment/2013/jun/12/ farmers-fail-weather-wheat-crop (2013).

33. Oerke, E.-C. Crop losses to pests. J. Agri. Sci. 144, 31-43 (2006).

34. Madgwick, J. W. et al. Impacts of climate change on wheat anthesis and fusarium ear blight in the UK. Eur. J. Plant Pathol. 130, 117-131 (2011).

35. FAO. Mycotoxins in Grain. Food and Agriculture Organization of the United Nations. http://www.fao.org/wairdocs/x5008e/x5008e01.htm (1997).

36. Kaur, S., Dhaliwal, L. \& Kaur, P. Impact of climate change on wheat disease scenario in Punjab. J. Res. 45, 161-170 (2008).

37. Bencze, S., Vida, G., Balla, K., Varga-László, E. \& Veisz, O. Response of wheat fungal diseases to elevated atmospheric CO2 level. Cereal Res. Commun. 41, 409-419 (2013). 
38. AHDB. Field Drainage Guide. Agriculture and Horticulture Development Board (AHDB). https://cereals.ahdb.org.uk/media/725158/g68-ahdbfield-drainage-guide.pdf (2015).

39. Paustian, K. et al. Climate-smart soils. Nature 532, 49 (2016).

40. POST. Securing UK soil health. UK Parliament POSTNOTE Number 502. researchbriefings.files.parliament.uk/documents/POST-PN-0502/ POST-PN-0502.pdf (2015).

41. Vidal, J. Hi-tech agriculture is freeing the farmer from his fields. The Guardian. https://www.theguardian.com/environment/2015/oct/20/hi-tech-agriculture-is-freeing-farmer-from-his-fields (2015).

42. AHDB. Monitoring. https://cereals.ahdb.org.uk/monitoring.aspx (2018).

43. SRUC. Nutrient Budgeting. https://www.sruc.ac.uk/info/120605/soil_ and_nutrients/1551/nutrient_budgeting (2018).

44. CFA. The Cool Farm Tool. https://coolfarmtool.org/coolfarmtool/ (2016).

45. weatherlogistics.com. Seasonal Weather Predictions. https://www.weatherlogistics.com (2018).

46. AHDB. Fusarium Infection Risk Archive. AHDB Cereals \& Oilseeds. https:// cereals.ahdb.org.uk/monitoring/fusarium/fusarium-infection-risk-archive. aspx (2018).

47. Nicholson, P., Bayles, R. A. \& Jennings, P. Understanding the Basis of Resistance to Fusarium Head Blight in UK Winter Wheat (REFAM) (Home-Grown Cereals Authority, 2008).

48. Mondal, S. et al. Harnessing diversity in wheat to enhance grain yield, climate resilience, disease and insect pest resistance and nutrition through conventional and modern breeding approaches. Front. Plant Sci. 7, 991 (2016).

49. Wulff, B. B. \& Moscou, M. J. Strategies for transferring resistance into wheat: From wide crosses to GM cassettes. Front. Plant Sci. 5, 692 (2014).

50. Newbery, F., Qi, A. \& Fitt, B. D. Modelling impacts of climate change on arable crop diseases: Progress, challenges and applications. Curr. Opin. Plant Biol. 32, 101-109 (2016).

51. Lobell, D. B. et al. Prioritizing climate change adaptation needs for food security in 2030. Science 319, 607-610 (2008).

52. Lobell, D. B. \& Field, C. B. Global scale climate-crop yield relationships and the impacts of recent warming. Environ. Res. Lett. 2, 014002 (2007). 
Open Access This chapter is licensed under the terms of the Creative Commons Attribution 4.0 International License (http://creativecommons.org/licenses/ by $/ 4.0 /$ ), which permits use, sharing, adaptation, distribution and reproduction in any medium or format, as long as you give appropriate credit to the original author(s) and the source, provide a link to the Creative Commons licence and indicate if changes were made.

The images or other third party material in this chapter are included in the chapter's Creative Commons licence, unless indicated otherwise in a credit line to the material. If material is not included in the chapter's Creative Commons licence and your intended use is not permitted by statutory regulation or exceeds the permitted use, you will need to obtain permission directly from the copyright holder.

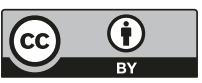

